\title{
Cytochrome P4501A Biomarker Indication of the Timeline of Chronic Exposure of Barrow's Goldeneyes to Residual Exxon Valdez Oil
}

\author{
Daniel Esler ${ }^{\mathrm{a}, *}$, Brenda E. Ballachey ${ }^{\mathrm{b}}$, Kimberly A. Trust ${ }^{\mathrm{c}}$, Samuel A. Iverson ${ }^{\mathrm{a}, 1}$, John A. \\ Reed $^{\text {b }}$, A. Keith Miles ${ }^{\mathrm{d}}$, John D. Henderson ${ }^{\mathrm{e}}$, Bruce R. Woodin ${ }^{\mathrm{f}}$, John J. Stegeman ${ }^{\mathrm{f}}$, \\ Malcolm McAdie ${ }^{\mathrm{g}}$, Daniel M. Mulcahy ${ }^{\mathrm{b}}$, and Barry W. Wilson ${ }^{\mathrm{e}}$.
}

\footnotetext{
${ }^{a}$ Centre for Wildlife Ecology, Simon Fraser University, 5421 Robertson Road, Delta, BC V4K 3N2 Canada

${ }^{\mathrm{b}}$ U.S. Geological Survey, Alaska Science Center, 4210 University Drive, Anchorage, AK 99508

${ }^{\mathrm{c}}$ U.S. Fish and Wildlife Service, 1011 E. Tudor Road, Anchorage, AK 99503

${ }^{\mathrm{d} U . S . ~ G e o l o g i c a l ~ S u r v e y, ~ W e s t e r n ~ E c o l o g i c a l ~ R e s e a r c h ~ C e n t e r, ~ D a v i s ~ F i e l d ~ S t a t i o n, ~} 1$ Shields Avenue, University of California, Davis, CA 95616

${ }^{\mathrm{e}}$ Animal Sciences and Environmental Toxicology, 1 Shields Avenue, University of California, Davis, CA 95616

f Department of Biology, Woods Hole Oceanographic Institution, Woods Hole, MA 02543

g 5206 Burnham Crescent, Nanaimo, BC V9T 2H9 Canada
}

*Corresponding author. Tel.: 604 940-4652; fax: 604 946-7022. Email address: desler@ sfu.ca (D. Esler).

\footnotetext{
${ }^{1}$ Present address: Department of Biology, Carleton University, Ottawa, ON K1S 5B6 Canada
} 


\begin{abstract}
We examined hepatic EROD activity, as an indicator of CYP1A induction, in Barrow's goldeneyes captured in areas oiled during the 1989 Exxon Valdez spill and those from nearby unoiled areas. We found that average EROD activity differed between areas during 2005, although the magnitude of the difference was reduced relative to a previous study from 1996/97, and we found that areas did not differ by 2009. Similarly, we found that the proportion of individuals captured from oiled areas with elevated EROD activity ( $\geq 2$ times unoiled average) declined from $41 \%$ in winter $1996 / 97$ to $10 \%$ in 2005 and $15 \%$ in 2009 . This work adds to a body of literature describing the timelines over which vertebrates were exposed to residual Exxon Valdez oil and indicates that, for Barrow's goldeneyes in Prince William Sound, exposure persisted for many years with evidence of substantially reduced exposure by 2 decades after the spill. Keywords: Alaska, Bucephala islandica, CYP1A, Exposure, Exxon Valdez, Oil
\end{abstract}




\section{Introduction}

Some of the oil released during the 1989 Exxon Valdez oil spill has remained in intertidal sediments of Prince William Sound, Alaska over the subsequent two decades (Boehm et al., 2008; Short et al., 2004; Short et al., 2006). Estimates of the quantity remaining (Boehm et al., 2008; Short et al., 2004) represent a small fraction of the oil that originally settled on Prince William Sound beaches following the spill (Wolfe et al., 1994), with residual oil in intertidal areas estimated to exceed 50,000 kg in 2001 (Short et al., 2004). Concern and debate persist over whether vertebrates continue to be exposed to the remaining oil and, if so, whether that exposure negatively affects individuals or populations.

Exposure of vertebrates to residual Exxon Valdez oil has been assessed by the use of indicators of induction of specific members of the cytochrome P4501 gene family. Members of the cytochrome P4501A (CYP1A) gene subfamily in vertebrates are induced by polycyclic aromatic hydrocarbons (PAH) found in crude oil, as well as certain halogenated aromatic hydrocarbons including planar polychlorinated biphenyls (PCB) and dioxins (Goksøyr, 1995; Payne et al., 1987; Whitlock, 1999; Woodin et al., 1997). Because CYP1As are induced by a limited number of compounds, measures of induction of CYP1A mRNA, protein, or resulting enzyme activity are particularly useful biomarkers for evaluating exposure to those contaminants (Whyte et al., 2000). Elevated enzyme activity does not directly indicate compromised survival or health of individuals (Lee and Anderson, 2005); however, it does indicate exposure to inducing compounds at levels sufficient to elicit a biochemical response and, thus, at least the potential for associated toxic consequences. 
Measurement of hepatic 7-ethoxyresorufin-O-deethylase (EROD) activity, a catalytic function of hydrocarbon-inducible CYP1 enzymes, is a widely used and recognized method for indicating CYP1 induction. There are multiple CYP1 genes in vertebrates. Two CYP1A genes (CYP1A4 and CYP1A5) have been identified in birds, both of which are inducible by aryl hydrocarbon receptor (AHR) agonists and both of which catalyze EROD activity (Kubota et al., 2009; Rifkind et al., 1994). EROD activity has been shown to be a reliable indicator of oil exposure in birds generally and sea ducks specifically (Esler, 2008; Miles et al., 2007).

Elevated indicators of CYP1A induction have been documented in a number of vertebrate species sampled from areas of Prince William Sound, Alaska that received oil during the 1989 Exxon Valdez oil spill (Esler et al., 2010; Jewett et al., 2002; Trust et al., 2000). For example, harlequin ducks (Histrionicus histrionicus), which forage in the intertidal zone, were shown to have elevated EROD activity when collected from oiled areas of Prince William Sound relative to unoiled areas, during the years 1998 to 2009 (Esler et al., 2010; Trust et al., 2000). Evidence of PAH exposure coincided with evidence of injury to individuals and populations of some vertebrates for at least a decade following the Exxon Valdez spill (Bodkin et al., 2002; Esler et al., 2000, 2002), although evidence of exposure persisted in some vertebrates beyond the period when gross demographic injury was evident and populations were projected to be recovering (Esler and Iverson, 2010; Iverson and Esler, 2010). The timeline over which exposure and injury were documented was an unanticipated finding stemming from the large body of research following the Exxon Valdez spill (Peterson et al., 2003). For example, mortalities of harlequin ducks thought to be related to chronic exposure to oil were 
estimated to exceed the acute mortality that occurred in the weeks and months immediately following the spill (Iverson and Esler, 2010), which is commonly perceived as the period of highest damage.

Trust et al. (2000) found that Barrow's goldeneyes (Bucephala islandica), a common sea duck in the area contaminated by the 1989 Exxon Valdez oil spill, had elevated EROD activity during winter 1996-97, which was interpreted as evidence of continued exposure to lingering oil. Wintering Barrow's goldeneyes in Prince William Sound inhabit nearshore areas and forage primarily on blue mussels (Mytilus trossulus) in the intertidal zone (Esler, 2000; Koehl et al., 1982; Vermeer, 1982) where much of the residual Exxon Valdez oil persisted (Short el al., 2004; Short et al., 2006).

Because of the evidence of exposure to oil nearly a decade after the spill (Trust et al., 2000) and their potential vulnerability for exposure as long as oil remains in intertidal sediments, we compared EROD activity in Barrow's goldeneyes captured in oiled and unoiled areas of Prince William Sound, Alaska during March 2005 and March 2009. Sea ducks generally have high levels of winter site fidelity (Iverson and Esler, 2006) and thus we assumed that movements of birds between oiled and unoiled areas were unlikely and therefore would not influence our inferences about differences in EROD activity in birds from different areas. Satellite telemetry data from adult male Barrow's goldeneye marked in Prince William Sound confirm high winter site fidelity (W.S. Boyd, Environment Canada, unpublished data). We also accounted for variation related to individual attributes, in case these confounded interpretation of area effects (Lee and Anderson, 2005). 


\section{Materials and Methods}

Evidence of CYP1A induction in wintering Barrow's goldeneyes in Prince William Sound, Alaska, was evaluated by measuring hepatic EROD activity, which required capture of wintering Barrow's goldeneyes, surgery to nonlethally remove a liver biopsy, and subsequent laboratory analysis. To facilitate comparisons to previous work on Barrow's goldeneyes, we designed the study and procedures per Trust et al. (2000).

\subsection{Capture and sample collection}

We captured Barrow's goldeneyes using floating mist nets in March 2005 and 2009. Barrow's goldeneyes winter in Prince William Sound between October and May. Our capture period in March was designed to capture individuals that had been on sampling sites all winter, but before pre-migratory movements, including local movements that some sea ducks exhibit in relation to Pacific herring (Clupea pallasi) spawn (Lok et al., 2008; Rodway et al., 2003). Barrow's goldeneyes were captured in a number of sites in Prince William Sound oiled during the Exxon Valdez spill, including Bay of Isles $\left(60^{\circ} 22^{\prime} \mathrm{N}, 147^{\circ} 40^{\prime} \mathrm{W}\right)$, Herring Bay $\left(60^{\circ} 28^{\prime} \mathrm{N}, 147^{\circ} 44^{\prime} \mathrm{W}\right)$, Crafton Island $\left(60^{\circ} 29^{\prime} \mathrm{N}, 147^{\circ} 57^{\prime} \mathrm{W}\right)$, Falls Bay $\left(60^{\circ} 32^{\prime} \mathrm{N}, 148^{\circ} 01^{\prime} \mathrm{W}\right)$, Green Island $\left(60^{\circ} 18^{\prime} \mathrm{N}, 147^{\circ} 24^{\prime} \mathrm{W}\right)$, and Foul Pass $\left(60^{\circ} 29^{\prime} \mathrm{N}, 147^{\circ} 38^{\prime} \mathrm{W}\right)$. These sites were documented as having received oil during the Exxon Valdez spill; contemporary occurrence or distribution of residual oil was not known for each specific sampling site within the oiled area. Also, birds were captured at unoiled reference sites on nearby northwestern Montague Island (60 $\left.{ }^{\circ} 15^{\prime} \mathrm{N}, 147^{\circ} 12^{\prime} \mathrm{W}\right)$ and Culross Passage $\left(60^{\circ} 43^{\prime} \mathrm{N}\right.$, $\left.148^{\circ} 15^{\prime} \mathrm{W}\right)$, which were reported to have not received oil during the Exxon Valdez spill. Sex of each bird was determined by plumage and cloacal characteristics, and age class 
was determined by the depth of the bursa of Fabricius (Mather and Esler, 1999) for females and bursal depth and plumage characteristics for males. Age class was summarized as either hatch-year (HY, i.e., hatched the previous breeding season) or afterhatch-year (AHY).

A liver biopsy ( $<0.5 \mathrm{~g}$ and $<5 \mathrm{~mm}$ diameter) was surgically removed by a veterinarian from each anesthetized Barrow's goldeneye. The biopsy was then placed into a labeled cryovial and flash frozen in liquid nitrogen. All samples were maintained at $-80^{\circ} \mathrm{C}$ until laboratory analysis. The birds were held until full recovery and then released near the location of capture.

\subsection{Laboratory analyses}

EROD activity was measured at 2 laboratories: 2005 samples were analyzed at Woods Hole Oceanographic Institution and 2009 samples at the University of California Davis using methods described in detail by Trust et al. (2000) and Miles et al. (2007), respectively. Paired liver samples of harlequin ducks captured in 2005 were analyzed in both labs and comparisons confirmed that the labs gave consistent results and inferences (Esler et al., 2010). All lab analyses were conducted without a priori knowledge of the areas from which the samples were collected. The measure of EROD activity is expressed in picomoles per minute per milligram of protein, i.e., $\mathrm{pmol} / \mathrm{min} / \mathrm{mg}$ protein.

\subsection{Statistical analyses}

We evaluated sources of variation in hepatic EROD activity of Barrow's goldeneyes. We analyzed data from each winter (2005 and 2009) separately because of the potential for variation between laboratory runs (Esler, 2008). Within each year, our analysis was designed to determine whether area (oiled versus unoiled) explained 
variation in EROD activity, after accounting for any effects of age class, sex, and body mass. We used least squares general linear models (GLM) using SAS 9.1 to estimate variation explained by each of a candidate set of models that included different combinations of variables of interest, and an information-theoretic approach to model selection and inference in which support for various model configurations was contrasted using Akaike's Information Criterion (AIC; Burnham and Anderson, 2002). We included or excluded age, sex, and body mass variables (which we termed "individual attributes") as a group, i.e., models either included all of these variables or none of them. We used singular and additive combinations of area and individual attribute effects, resulting in a candidate model set including: (1) EROD = area; (2) EROD = individual attributes; and (3) $\mathrm{EROD}=$ area + individual attributes. We also included a null model, which consisted of estimates of a mean and variance across all of the data; strong support for the null model would indicate that variables considered in other candidate models did not explain important variation in the response.

The model with the lowest $\mathrm{AIC}$ value corrected for small sample size $\left(\mathrm{AIC}_{\mathrm{c}}\right)$ was considered to have the strongest support from the data among the models considered. Another metric, $\mathrm{AIC}_{\mathrm{c}}$ weight $(w)$, was calculated for each model; $\mathrm{AIC}_{\mathrm{c}}$ weights sum to 1.0 across the entire model set and provide a measure of relative support for candidate models. The variables included in the models with highest support are considered to explain important variation in the response. Parameter likelihoods, which are the sums of $w$ for all models including a given parameter, indicate the relative support for that variable, taking into account model uncertainty. Parameter likelihoods close to 1 indicate strong support. Finally, we calculated weighted parameter estimates and associated 
unconditional standard errors, which are estimates of the size, direction, and associated variation of effects of variables calculated across the set of candidate models.

To evaluate trends in EROD activity over time, we applied corrections to account for between-year differences in reported values. Between-year EROD values varied substantially across laboratory runs. In consultation with the laboratories, we confirmed that, although within-year comparisons between areas were valid, between-year comparisons were not appropriate without correction (Esler, 2008). Therefore, we created an index for CYP1A values, in which we set average EROD activity for Barrow's goldeneyes that we captured at our unoiled areas (Montague Island and Culross Passage) to 1 for each year, and we adjusted all values accordingly within the same sample year (Esler, 2008). When comparing data across years, this index assumes that oil exposure, and hence EROD activity, at unoiled sites was the same across years, which is reasonable because these are relatively pristine areas with little inter-annual variation in human activity and, hence, little variation in occurrence or concentrations of CYP1A-inducing compounds. Indexed values and their associated variation were graphically contrasted across years and oiling history status. For each year, we also calculated the proportion of individuals captured in oiled areas with elevated EROD activity, which we defined as a value $\geq 2$ times the average value on unoiled areas for that year. We recognize that this criteria for elevation is arbitrary, but is one that we considered to represent a biologically meaningful difference in CYP1A expression. This metric was designed to evaluate whether the incidence of exposure changed over time. 


\section{Results}

We captured 79 Barrow's goldeneyes over the course of our study; sample sizes by year, area, sex, and age are described in Table 1. For samples collected in 2005, the model with area and individual attributes as explanatory variables $(w=0.44)$ and the model with area only $(w=0.41)$ had essentially equivalent support (Table 2$)$. The best supported model had an $\mathrm{R}^{2}$ of 0.30 . The remaining two models had little support (Table 2), with differences in $\mathrm{AIC}_{\mathrm{c}}$ values from the best-supported model $\left(\Delta \mathrm{AIC}_{\mathrm{c}}\right)$ of $>3.0$ and $w<0.10$. These findings indicated that area explained important variation in EROD activity in 2005, with some support for explanatory value of individual attributes. This inference was supported by examination of parameter likelihoods and weighted parameter estimates and their associated unconditional SE (Table 3). The high parameter likelihood for area, along with the positive parameter estimate that was higher than the associated SE, indicated that average EROD activity was higher in birds from oiled areas, after accounting for any effects of individual attributes. The individual attributes of sex, age, and mass had a more modest parameter likelihood and unconditional SEs that exceeded the absolute values of the parameter estimates in all cases, suggesting that these had modest explanatory value for 2005 data.

Results for 2009 data indicated different patterns than those from 2005. In 2009, the best-supported model for explaining variation in EROD activity included only individual attributes as explanatory variables (Table 2); the $\mathrm{R}^{2}$ for this model was 0.30 . Other models, including those with an area term, were not well supported, with $\Delta \mathrm{AIC}_{\mathrm{c}}>$ 2.7 and $w<0.20$. These results indicated that average EROD activity did not differ between birds from oiled and unoiled areas during 2009, which was supported by the 
small parameter likelihood for the area variable, as well as the small absolute value of the weighted parameter estimate for area relative to the associated unconditional SE (Table 3). There was strong support for effects of individual attributes, with a parameter likelihood of 0.96. Age provided little explanatory value, as the SE exceeded the absolute value of the parameter estimate. However, both sex and mass seemed to explain important variation in EROD in 2009. Specifically, females had lower average EROD activity than males, and EROD activity was negatively related to body mass (Table 3 ).

We found that hepatic EROD activity in Barrow's goldeneye captured in oiled areas during 2005 and 2009 was lower than that reported by Trust et al. (2000) for 1996/97, after scaling to allow direct contrasts (Figure 1). Average EROD activity was 1.9, 1.4, and 1.3 times higher in birds from oiled areas relative to birds from unoiled areas in 1996/97, 2005, and 2009, respectively. We interpret this result to indicate that exposure to oil declined through time, which was consistent with analytical support for an area effect on EROD activity during 1996/97 and 2005, but not 2009. Similarly, we found that the proportions of individuals captured on oiled areas with elevated hepatic EROD activity were lower in 2005 and 2009 than during 1996/97 (Trust et al., 2000; Figure 2). Specifically, 41, 10, and 15\% of Barrow's goldeneye captured on oiled areas during 1996/97, 2005, and 2009, respectively, had elevated EROD activity relative to individuals captured on unoiled areas during the same year; we interpret this as additional evidence of declining exposure over time. 


\section{Discussion}

We found that the degree and incidence of elevated hepatic EROD activity of Barrow's goldeneyes from oiled areas of Prince William Sound were considerably lower in our study relative to the findings of Trust et al. (2000) from 1996/97. This was evident in reductions in point estimates of scaled EROD activity of individuals from oiled areas over time, lack of a statistical difference in average EROD activity between oiled and unoiled areas in the most recent data (2009), and reductions in the proportion of individuals identified as having elevated EROD activity between 1996/97 and the current study. In summary, these findings are consistent with the conclusion that PAH exposure of Barrow's goldeneyes living in parts of Prince William Sound oiled by the Exxon Valdez has declined to the point where it is approaching levels similar to unoiled areas.

These findings contribute to a body of literature describing timelines over which exposure and injury were observed. In this case, demographic injuries (e.g., survival rates) were never investigated, but our work provides a time scale that is relevant for considering potential population injury following oil spills. Given our findings, we suggest that oil exposure had declined markedly by 16 and 20 years following the 1989 Exxon Valdez spill, although we recognize that as long as oil remains in the environment, some individuals are likely to encounter it (Short et al., 2006). In the case of Barrow's goldeneyes, it appears that the incidence and degree of any remaining exposure was low by 2009. However, our data suggest that some individuals may still be exposed. For example, despite lack of a statistical difference between areas in average EROD in 2009, the point estimate for EROD activity on oiled areas was higher than that on unoiled areas, and the variance around that estimate was high (Fig. 1). This resulted from values for 2 
individuals captured in oiled areas (10\% of our sample from oiled areas in 2009) that were markedly higher $(7 \mathrm{x}$ and $4 \mathrm{x})$ than the average from the unoiled areas. Excluding those 2 individuals, the point estimate for average EROD was slightly lower on oiled areas than unoiled areas. Therefore, although oil exposure in 2009 had declined markedly relative to $1996 / 97$, complete cessation of exposure for all individuals may not occur until residual oil no longer occurs in intertidal habitats. Overall, our results contribute to growing evidence that exposure of some vertebrates to lingering oil persisted much longer than originally anticipated (Esler et al., 2010), measured on scales of decades in some cases, rather than weeks, months, or years (Peterson et al., 2003). Results contrast with findings for harlequin ducks, another sea duck, which were found to exhibit elevated EROD activity in oiled areas through 2009 (Esler et al., 2010). Hepatic EROD activity in harlequin ducks from oiled areas was roughly 4 times that of harlequin ducks from unoiled areas in 2009, a difference greater in magnitude than for Barrow's goldeneyes in any year (Figure 1). This result indicated that harlequin ducks continued to be exposed to residual Exxon Valdez oil for at least 2 decades following the spill (Esler et al., 2010). Differences between Barrow's goldeneyes and harlequin ducks could be due to (a) their different natural histories or (b) differences in their physiological response to exposure. Although both species feed on benthic invertebrates in intertidal habitats, their specific food types differ, which could result in different degrees of exposure. Barrow's goldeneyes feed almost exclusively on mussels, which are epibenthic and were shown to have low amounts of hydrocarbons by the time of our studies in areas oiled by the Exxon Valdez (Payne et al., 2008). In contrast, harlequin ducks consume some invertebrates that occur within intertidal sediments, e.g., 
polychaetes, amphipods, snails, which may result in higher levels of hydrocarbons in the prey or disturbance of residual oil when foraging. However, inherent species differences in CYP1A response have been speculated (Miles et al., 2007), and this is plausible for explaining differences between Barrow's goldeneyes and harlequin ducks.

As described for some fish (Goksøyr and Larsen, 1991; Kammann et al., 2005;

Sleiderink et al., 1995; Whyte et al., 2000), we found subtle effects of individual attributes, particularly in 2009. Specifically, males had higher average EROD activity and body mass was negatively related to EROD activity. Sex differences had not been found in harlequin ducks (Esler et al., 2010) or Barrow's goldeneye in previous sampling periods. A subtle negative relationship between body mass and EROD was detected in harlequin ducks from winter 1998 (Esler et al., 2002), but not in harlequin ducks (Esler et al., 2010) or Barrow's goldeneyes in most periods since 1998. Evidence for a slight relationship between body mass and EROD in Barrow's goldeneyes in 2009 was surprising, particularly because there was little evidence of elevation in most individuals. We do not know whether our results for 2009 are spurious (i.e., artifacts of this specific data set) or whether they reflect patterns in the population of interest.

Some authors have questioned whether oil spilled during the Exxon Valdez event can be assumed to be the primary source of CYP1A inducing compounds in oiled areas of Prince William Sound (Harwell and Gentile, 2006), recognizing that there may be multiple CYP1A-inducing compounds from multiple sources within a given area (Lee and Anderson, 2005). However, studies indicate that PAHs in the areas where elevated CYP1A was observed in vertebrates are predominately from the Exxon Valdez (Short et al., 2004), supporting the inference that Exxon Valdez oil was the inducing agent. Also, 
other studies (Trust et al., 2000; Ricca et al., 2010) considered the potential role of PCBs in observed CYP1A indication in harlequin ducks in Prince William Sound and determined that concentrations were very low and generally not related to CYP1A induction. In addition, Short et al. (2006) calculated that, given the distribution of residual Exxon Valdez oil through 2003, benthic foraging vertebrates were likely to encounter lingering oil during routine foraging activities. Finally, our results indicating declines in CYP1A induction in Barrow's goldeneye over time were consistent with exposure to a source declining in availability over time, as would be expected with Exxon Valdez oil, rather than compounds predicted as constant over time such as atmospheric PCBs or oil from natural seeps. Our results for Barrow's goldeneyes were encouraging in that they indicated declining exposure to residual Exxon Valdez oil in a previouslyexposed species and, hence, progress towards ecosystem recovery.

\section{Acknowledgements}

This research was supported primarily by the Exxon Valdez Oil Spill Trustee Council. However, the findings and conclusions do not necessarily reflect the views or position of the Trustee Council. Any use of trade names is for descriptive purposes only and does not represent endorsement by the U.S. government. Procedures described in this manuscript were approved by the Simon Fraser University Animal Care Committee. We thank those who helped with field work, under frequently difficult winter conditions, including: A. Birmingham, T. Bowman, S. Davis, T. Donnelly, M. Maftei, D. Rizzolo, N. Slosser, B. Uher-Koch, and K. Wright. Dr. D. Heard provided additional veterinary expertise during field work. We thank D. Rand and his crew of the motor vessel 
Discovery for safe and comfortable passage. We also appreciate the institutional support provided by D. Derksen, D. Bohn, R. Ydenberg, M. Court, C. Smith, I. Semple, and the Pacific Wildlife Foundation.

\section{References}

Bodkin, J.L., Ballachey, B.E., Dean, T.A., Fukuyama, A.K., Jewett, S.C., McDonald, L., Monson, D.H., O’Clair, C.E., VanBlaricom, G.R., 2002. Sea otter population status and the process of recovery from the 1989 'Exxon Valdez' oil spill. Marine Ecology Progress Series 241, 237-253.

Boehm, P.D., Page, D.S., Brown, J.S., Neff, J.M., Bragg, J.R., Atlas, R.M., 2008. Distribution and weathering of crude oil residues on shorelines 18 years after the Exxon Valdez spill. Environmental Science and Technology 42, 9210-9216.

Burnham, K.P., Anderson, D.R., 2002. Model selection and multimodel inference: a practical information theoretic approach, second ed. Springer-Verlag, New York.

Esler, D., 2000. Recovery status of Barrow's goldeneyes, Exxon Valdez Oil Spill Restoration Project Final Report (Restoration Project 00466), U.S. Geological Survey, Alaska Biological Science Center, Anchorage, Alaska.

Esler, D., 2008. Quantifying temporal variation in Harlequin Duck cytochrome P4501A induction. Exxon Valdez Oil Spill Trustee Council Gulf Ecosystem Monitoring and Research Project Final Report (GEM Project 050777). Centre for Wildlife Ecology, Simon Fraser University, Delta, British Columbia, Canada. 
Esler, D., Schmutz, J.A., Jarvis, R.L., Mulcahy, D.M., 2000. Winter survival of adult female harlequin ducks in relation to history of contamination by the Exxon Valdez oil spill. Journal of Wildlife Management 64, 839-847.

Esler, D., Bowman, T.D., Trust, K., Ballachey, B.E., Dean,T.A., Jewett, S.C., O’Clair, C.E., 2002. Harlequin duck population recovery following the Exxon Valdez oil spill: progress, process, and constraints. Marine Ecology Progress Series 241, 271-286.

Esler, D., Trust. K.A., Ballachey, B.E., Iverson, S.A., Lewis, T.L., Rizzolo, D.J., Mulcahy, D.M., Miles, A.K., Woodin, B.R., Stegeman, J.J., Henderson, J.D., Wilson, B.W., 2010. Cytochrome P4501A biomarker indication of oil exposure in harlequin ducks up to 20 years after the Exxon Valdez oil spill. Environmental Toxicology and Chemistry 29, 1138-1145.

Esler, D., Iverson, S.A., 2010. Female harlequin duck winter survival 11 to 14 years after the Exxon Valdez oil spill. Journal of Wildlife Management 74, 471-478.

Goksøyr, A., 1995. Use of cytochrome P450 1A (CYP1A) in fish as a biomarker of aquatic pollution. Archives of Toxicology Supplement 17, 80-95.

Goksøyr, A., Larsen, H.E., 1991. The cytochrome P450 system of the Atlantic salmon (Salmo salar): I. Basal properties and induction of P450 1A1 in liver of immature and mature fish. Fish Physiology and Biochemistry 9, 339-349. 
Harwell, M.A., Gentile, J.H., 2006. Ecological significance of residual exposures and effects from the Exxon Valdez oil spill. Integrated Environmental Assessment and Management 2, 204-246.

Iverson, S.A., Esler, D., 2006. Site fidelity and the demographic implications of winter movements by a migratory bird, the harlequin duck. Journal of Avian Biology 37, 219-228.

Iverson, S.A., Esler, D., 2010. Harlequin duck population dynamics following the 1989 Exxon Valdez oil spill: assessing injury and projecting a timeline to recovery. Ecological Applications 20, 1993-2006.

Jewett, S.C., Dean, T.A., Woodin, B.R., Hoberg, M.K., Stegeman, J.J., 2002. Exposure to hydrocarbons ten years after the Exxon Valdez: evidence from cytochrome P4501A expression and biliary FACs in nearshore demersal fishes. Marine Environmental Research 54, 21-48.

Kammann, U., Lang, T., Vobach, M., Wosniok, W., 2005. Ethoxyresorufin-O-deethylase (EROD) activity in dab (Limanda limanda) as biomarker for marine monitoring. Environmental Science and Pollution Research 12, 140-145.

Koehl, P.S., Rothe, T.C., Derksen, D.V., 1982. Winter food habits of Barrow's goldeneyes in southeast Alaska, in: Nettleship, D.N., Sanger, G.A., Springer, P.F. (Eds.), Proceedings of the Pacific Seabird Group Symposium. Canadian Wildlife Service Special Publication, Ottowa, Ontario, Canada, pp. 1-5. 
Kubota, A., Kim. E.Y., Iwata, H., 2009. Alkoxyresorufin (methoxy-, ethoxy-, pentoxyand benzyloxyresorufin) O-dealkylase activities by in vitro-expressed cytochrome P450 1A4 and 1A5 from common cormorant (Phalacrocorax carbo). Comparative Biochemistry and Physiology C 149, 544-551.

Lee, R.F., Anderson, J.W., 2005. Significance of cytochrome P450 system responses and levels of bile fluorescent aromatic compounds in marine wildlife following oil spills. Marine Pollution Bulletin 50, 705-723.

Lok, E.K., Kirk, M., Esler, D., Boyd, W.S., 2008. Movements of pre-migratory surf and white-winged scoters in response to Pacific herring spawn. Waterbirds 31, 385393.

Mather, D.D., Esler, D., 1999. Evaluation of bursal depth as an indicator of age class of harlequin ducks. Journal of Field Ornithology 70, 200-205.

Miles, A.K., Flint, P.L., Trust, K.A., Ricca, M.A., Spring, S.E., Arietta, D.E., Hollmén, T., Wilson, B.W., 2007. Polycyclic aromatic hydrocarbon exposure in Steller's eiders (Polysticta stelleri) and harlequin ducks (Histrionicus histrionicus) in the eastern Aleutian Islands, Alaska. Environmental Toxicology and Chemistry 26, 2694-2703.

Payne, J.F., Fancey, L.L., Rahimtula, A.D., Porter, E.L., 1987. Review and perspective on the use of mixed-function oxygenase enzymes in biological monitoring. Comparative Biochemistry and Physiology C 86, 233-245. 
Payne, J.R., Driskell, W.B., Short, J.W., Larsen, M.L., 2008. Long term monitoring for oil in the Exxon Valdez spill region. Marine Pollution Bulletin 56, 2067-2081.

Peterson, C.H., Rice, S.D., Short, J.W., Esler, D., Bodkin, J.L., Ballachey, B.A., Irons, D.B., 2003. Long-term ecosystem response to the Exxon Valdez oil spill. Science 302, 2082-2086.

Ricca, M.A., Miles, A.K., Ballachey, B.E., Bodkin, J.L., Esler, D., Trust, K.A., 2010. PCB exposure in sea otters and harlequin ducks in relation to history of contamination by the Exxon Valdez oil spill. Marine Pollution Bulletin 60, 861872.

Rifkind, A.B., Kanetoshi, A., Orlinick, J., Capdevila, J.H., Lee, C. 1994., Purification and biochemical characterization of two major cytochrome P-450 isoforms induced by 2,3,7,8-tetrachlorodibenzo-p-dioxin in chick embryo liver. Journal of Biological Chemistry 269, 3387-3396.

Rodway, M.S., Regehr, H.M., Ashley, J., Clarkson, P.V., Goudie, R.I., Hay, D.E., Smith, C.M., Wright, K.G., 2003. Aggregative response of Harlequin Ducks to herring spawning in the Strait of Georgia, British Columbia. Canadian Journal of Zoology $81,504-514$.

Short, J.W., Lindeberg, M.R., Harris, P.M., Maselko, J.M., Pella, J.J., Rice, S.D., 2004. Estimate of oil persisting on the beaches of Prince William Sound 12 years after the Exxon Valdez oil spill. Environmental Science and Technology 38, 19-25.

Short, J.W., Maselko, J.M., Lindeberg, M.R., Harris, P.M., Rice, S.D., 2006. Vertical distribution and probability of encountering intertidal Exxon Valdez oil on 
shorelines of three embayments within Prince William Sound. Environmental Science and Technology 40, 3723-3729.

Sleiderink, H.M., Oostingh, I., Goksøyr, A., Boon, J.P., 1995. Sensitivity of cytochrome P450 1A induction in dab (Limanda limanda) of different age and sex as a biomarker for environmental contaminants in the southern North Sea. Archives of Environmental Contamination and Toxicology 28, 423-430.

Trust, K.A., Esler, D., Woodin, B.R., Stegeman, J.J., 2000. Cytochrome P450 1A induction in sea ducks inhabiting nearshore areas of Prince William Sound, Alaska. Marine Pollution Bulletin 40, 397-403.

Vermeer, K., 1982. Food and distribution of three Bucephala species in British Columbia waters. Wildfowl 33, 22-30.

Whitlock, J.P., Jr., 1999. Induction of cytochrome P4501A1. Annual Review of Pharmacology and Toxicology 39, 103-125.

Whyte, J.J., Jung, R.E., Schmitt, C.J., Tillitt, D.E., 2000. Ethoxyresorufin-O-deethylase (EROD) activity in fish as a biomarker of chemical exposure. Critical Reviews in Toxicology 30, 347-570.

Woodin, B.R., Smolowitz, R.M., Stegeman,J.J., 1997. Induction of cytochrome P450 1A in the intertidal fish A. purpurescens by Prudhoe Bay crude oil and environmental induction in fish from Prince William Sound. Environmental Science and Technology 31, 1198-1205. 
Wolfe, D.A., Hameedi, M.J., Galt, J.A., Watabayashi, G., Short, J., O’Clair, C., Rice, S., Michel, J., Payne, J.R., Braddock, J., Hanna, S., Sale, D., 1994. The fate of the oil spilled from the Exxon Valdez. Environmental Science and Technology 28, 561568. 
Table 1. Sample sizes of Barrow's goldeneyes captured in Prince William Sound, Alaska for analyses of EROD activity as an indicator of cytochrome P4501A induction.

Numbers are listed by sampling period, sex and age class cohort, and capture area (oiled during Exxon Valdez oil spill versus unoiled).
$\underline{\operatorname{March} 2005}$
March 2009

Cohort $^{\mathrm{a}} \quad$ Oiled Unoiled $\quad$ Oiled Unoiled

$\begin{array}{lrrrr}\text { AHY M } & 14 & 17 & 14 & 10 \\ \text { HY M } & 1 & 0 & 1 & 2 \\ \text { AHY F } & 5 & 1 & 4 & 4 \\ \text { HY F } & 0 & 1 & 3 & 2 \\ \text { TOTAL } & \mathbf{2 0} & \mathbf{1 9} & \mathbf{2 2} & \mathbf{1 8}\end{array}$

${ }^{\mathrm{a}}$ Cohort consists of an age class designation (HY = hatch-year, i.e., within one year of hatching; $\mathrm{AHY}=$ after-hatch-year $)$ and $\operatorname{sex}(\mathrm{M}=$ male; $\mathrm{F}=$ female $)$. 
Table 2. Results of information-theoretic analyses using general linear models to evaluate variation in hepatic EROD activity of Barrow's goldeneyes captured during March in Prince William Sound, Alaska.

\begin{tabular}{|c|c|c|c|c|c|c|c|}
\hline \multirow[b]{2}{*}{ Model } & \multirow[b]{2}{*}{$\mathrm{K}^{\mathrm{a}}$} & \multicolumn{3}{|c|}{2005} & \multicolumn{3}{|c|}{2009} \\
\hline & & $\mathrm{AIC}_{\mathrm{c}}^{\mathrm{b}}$ & $\Delta \mathrm{AIC}_{\mathrm{c}}{ }^{\mathrm{c}}$ & $w^{\mathrm{d}}$ & $\mathrm{AIC}_{\mathrm{c}}$ & $\Delta \mathrm{AIC}_{\mathrm{c}}$ & $w$ \\
\hline $\mathrm{EROD}=\mathrm{Area}^{\mathrm{e}}$ & 3 & 269.2 & 0.2 & 0.41 & 191.6 & 8.5 & 0.01 \\
\hline 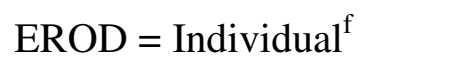 & 5 & 272.3 & 3.2 & 0.09 & 183.0 & 0.0 & 0.77 \\
\hline EROD $=$ Area + Individual & 6 & 269.1 & 0.0 & 0.44 & 185.8 & 2.8 & 0.19 \\
\hline EROD $=$ Null & 2 & 272.9 & 3.8 & 0.06 & 190.0 & 7.0 & 0.02 \\
\hline
\end{tabular}

${ }^{\mathrm{a}} \mathrm{K}=$ number of estimated parameters in the model.

${ }^{\mathrm{b}} \mathrm{AIC}_{\mathrm{c}}=$ Akaike's Information Criterion, corrected for small sample size.

${ }^{\mathrm{c}} \Delta \mathrm{AIC}_{\mathrm{c}}=$ difference in $\mathrm{AIC}_{\mathrm{c}}$ from the best supported model.

${ }^{\mathrm{d}} w=\mathrm{AIC}_{\mathrm{c}}$ weight.

${ }^{\mathrm{e}}$ Area $=$ categorical variable indicating areas either oiled during the Exxon Valdez spill or unoiled.

${ }_{\mathrm{f}}^{\mathrm{f}}$ Individual $=$ a grouping of variables describing attributes of individuals (age, sex, and mass). 
Table 3. Parameter likelihoods (P.L.), weighted parameter estimates, and unconditional standard errors (SE) derived from information-theoretic analyses using general linear models to evaluate variation in hepatic EROD activity ( $\mathrm{pmol} / \mathrm{min} / \mathrm{mg}$ protein) of Barrow's goldeneyes captured in Prince William Sound, Alaska during March 2005 and March 2009.

\begin{tabular}{|c|c|c|c|c|}
\hline \multirow[b]{2}{*}{ Parameter } & \multicolumn{2}{|c|}{ March 2005} & \multicolumn{2}{|c|}{ March 2009} \\
\hline & P.L. & Estimate $\pm \mathrm{SE}$ & P.L. & Estimate $\pm \mathrm{SE}$ \\
\hline Intercept & 1.00 & $-16.0 \pm 98.2$ & 1.00 & $89.5 \pm 31.5$ \\
\hline Area $^{a}$ & 0.85 & $19.2 \pm 11.4$ & 0.20 & $0.03 \pm 0.67$ \\
\hline $\operatorname{Sex}^{b}$ & 0.53 & $33.7 \pm 37.4$ & 0.96 & $-18.2 \pm 10.2$ \\
\hline $\mathrm{Age}^{\mathrm{c}}$ & 0.53 & $13.8 \pm 19.7$ & 0.96 & $2.0 \pm 3.8$ \\
\hline Mass (g) & 0.53 & $0.07 \pm 0.08$ & 0.96 & $-0.08 \pm 0.03$ \\
\hline
\end{tabular}

${ }^{\mathrm{a}}$ Area $=$ categorical variable indicating areas either oiled during the Exxon Valdez spill or unoiled, with unoiled as the reference value.

${ }^{\mathrm{b}} \mathrm{Sex}=$ categorical variable (male versus female), with male as the reference value.

${ }^{\mathrm{c}}$ Age $=$ categorical variable (hatch-year versus after-hatch-year), with hatch-year as the reference value. 


\section{Figure captions}

Figure 1. Average ( $\pm 95 \% \mathrm{CI})$ hepatic EROD activity of Barrow’s goldeneyes from winter 1996 and 1997 (Trust et al. 2000) and the present study (2005 and 2009) in areas oiled by the Exxon Valdez spill and unoiled areas of Prince William Sound, Alaska. Averages were adjusted such that all values within a given year were scaled relative to an average of 1.0 in unoiled areas in that year (see Esler 2008).

Figure 2. Percentage of Barrow's goldeneyes with elevated hepatic EROD activity that were captured in areas oiled by the Exxon Valdez spill in Prince William Sound, Alaska

during winter 1996 and 1997 (Trust et al. 2000) and during the present study (2005 and 2009). Elevated EROD activity is defined as $\geq 2$ times the average value of birds captured in unoiled areas during the same year. 
Esler et al., Figure 1.

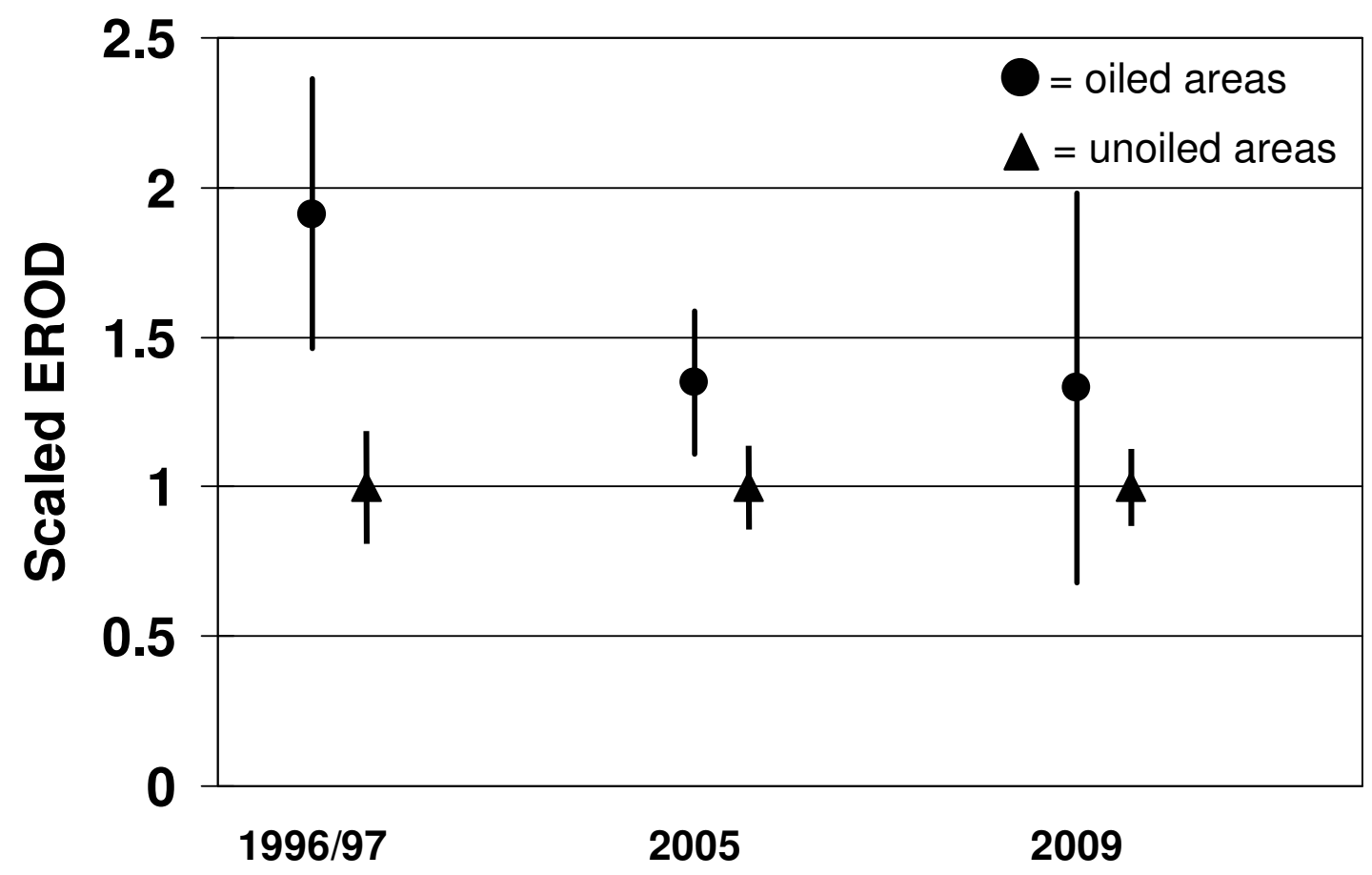


Esler et al., Figure 2.

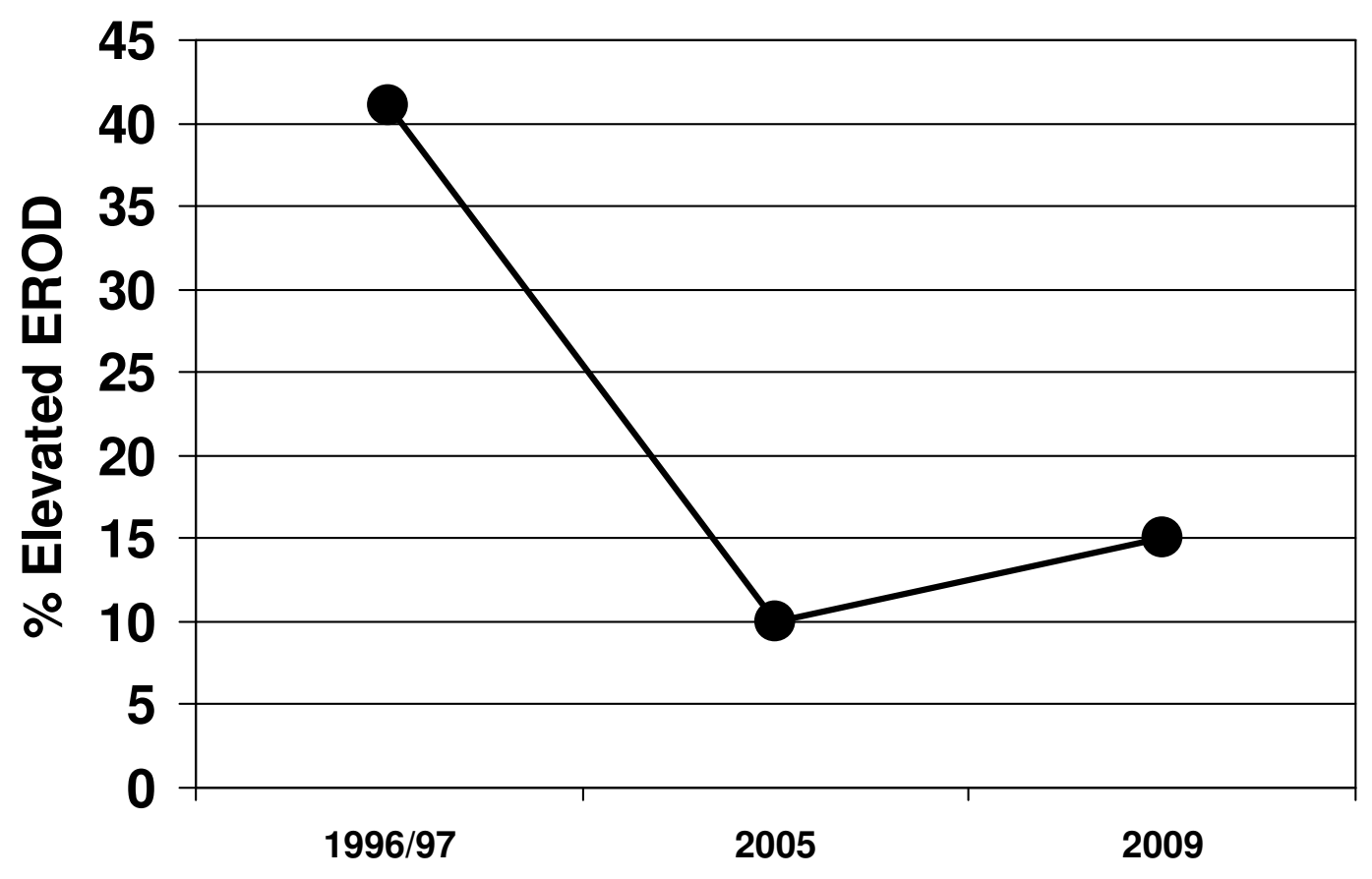

